\title{
Two New Lance-leaved Caladium Cultivars: Pink Panther and Crimson Skye
}

\section{Zhanao Deng}

University of Florida, Institute of Food and Agricultural Science, Department of Environmental Horticulture, Gulf Coast Research and Education Center, 14625 County Road 672, Wimauma, FL 33598

\author{
Natalia A. Peres \\ University of Florida, Institute of Food and Agricultural Science, \\ Department of Plant Pathology, Gulf Coast Research and Education \\ Center, 14625 County Road 672, Wimauma, FL 33598
}

\section{Johan Desaeger \\ University of Florida, Institute of Food and Agricultural Science, Department of Entomology and Nematology, Gulf Coast Research and Education Center, 14625 County Road 672, Wimauma, FL 33598}

Additional index words. disease resistance, landscape performance, ornamental aroid, ornamental plant, plant breeding, sunburn tolerance

Caladium (Caladium $\times$ hortulanum Birdsey, Araceae Juss.) is an ornamental aroid often grown in containers or planted in the landscape as accent and border plants (Deng, 2018; Evans et al., 1992). Caladium plants are valued for their variably shaped bright foliage. The majority of commercial caladium plants are produced by forcing tubers in containers. Florida growers produce essentially all the caladium tubers used in the United States and in the world for production of pot plants and for direct planting in the landscapes (Deng et al., 2018). Commercial caladium cultivars generally fall into one of the two major leaf types (fancy- or lance-leaved) (Bell et al., 1998). The majority of commercial cultivars are fancy-leaved; however, the demand for lance-leaved cultivars has been on rise for the past two or three decades. Florida caladium growers planted more than $50 \%$ more

Received for publication 16 Mar. 2021. Accepted for publication 14 Apr. 2021.

Published online 8 June 2021.

The development and evaluation of 'Pink Panther' and 'Crimson Skye' caladium were funded in part by the U.S. Department of Agriculture Hatch projects (project nos. FLA-GCR-005065 and FLA-GCC005507), Florida caladium growers' "box assessment," royalties from previously released caladium cultivars, and a legislature budget appropriation from the State of Florida Legislature in 2012.

We thank Keri Druffel, Joyce Jones, and Gail Bowman for their excellent technical support; and Bates Sons \& Daughters, Inc., and Heartland Caladiums, Inc., for evaluating 'Pink Panther' and/or 'Crimson Skye'.

Z.D. is the corresponding author. E-mail: zdeng@ufl.edu.

This is an open access article distributed under the CC BY-NC-ND license (https://creativecommons. org/licenses/by-nc-nd/4.0/). acres for this group of cultivars in 2003 than in 1998 (Bell et al., 1998; Deng et al., 2018).

So far, 'Florida Sweetheart' has had the largest acreage (42.7 acres in 2003) in Florida and has been the most popular among all lance-leaved cultivars (Deng et al., 2018). This cultivar is characterized by wide, rosy, cascading lance leaves. It produces high-quality plants in containers, and has superb performance in shady or sunny landscape locations (Wilfret, 1991b). It also has a high level of resistance to Fusarium tuber rot (Goktepe et al., 2007). 'Florida Sweetheart' was the first lance-leaved cultivar released by the University of Florida (UF) Institute of Food and Agricultural Science caladium breeding program. Subsequently, this breeding program released a red lance-leaved cultivar: Florida Red Ruffles (Wilfret, 1991a). With a compact growth habit, numerous dark-red leaves, excellent tolerance to sunburn, and reduced sensitivity to chilling (Deng and Harbaugh, 2006a), this cultivar has become the most popular red lanceleaved cultivar. To meet industry needs, lanceleaved cultivars Fairytale Princess and Red Hot were released in 2012 (Deng et al., 2013). However, the acreage for these two recent releases is still very limited. Two new lanceleaved cultivars, Pink Panther (Figs. 1 and 2) and Crimson Skye (Figs. 3 and 4), were released in 2020 to meet growers' need for more cultivars in this group.

Plants of 'Pink Panther' are characterized by a unique combination of leaf characteristics, wide lance leaves, upright and sturdy petioles, deep-pink main veins, light-pink blotches on the leaf blade, and slightly ruffled margins. In small-scale replicated trials, 'Pink Panther' showed very good tuber yield potential and produced high-quality plants in containers. Plants of 'Crimson Skye' are characterized by compact stature, numerous heart-shaped leaves, multiple pink blotches on each leaf, and a high level of uniformity in leaf shape and size. In tuber yield potential, 'Crimson Skye' is comparable to other lanceleaved cultivars. 'Crimson Skye' is well suited for producing high-quality prefinished and finished plants in containers with small (10 $\mathrm{cm})$ to large $(\geq 20 \mathrm{~cm})$ diameters. Tuber deeyeing is optional; when it is used, it improves pot plant quality. Both cultivars have shown good sunburn tolerance and bacterial blight disease tolerance, and they are suitable for use in a range of landscape conditions, from full sun to shady locations.

\section{Origin}

'Pink Panther' originated from a cross between 'Carolyn Whorton' and a breeding line UF-4609 that was made in Balm, FL, in Summer 2012 (Fig. 5). Breeding line UF-4609 was the progeny of a cross between 'Cranberry Star' (initially breeding line 7537) and 'Florida Sweetheart' made in 2004. 'Carolyn Whorton' is a unpatented commercial cultivar, whereas 'Cranberry Star' is a patented commercial cultivar released in 2008 (Deng et al., 2008). 'Florida Sweetheart' was a patented cultivar, but its patent expired. 'Pink Panther' was initially selected in Sept. 2015 as breeding line 1220-9, which was then recoded as 15-55 in Apr. 2016. 'Crimson Skye' originated from a cross between a propriety caladium breeding line UF477 and 'Carolyn Whorton', which was made in Balm, FL, in Summer 2012 (cross no. 1217R) (Fig. 6). UF-477 was the progeny of 'Florida Sunrise' (Wilfret, 1993) and 'Florida Sweetheart' (Wilfret, 1991b). 'Crimson Skye' was initially selected in Sept. 2015 as breeding line 1217R-64, which was recoded as UF-15-54 in Apr. 2016. The first asexual propagation of 'Pink Panther' and 'Crimson Skye' occurred in Balm, FL, in Spring 2014. Since then, they have been propagated asexually through tuber division for six generations. Plant, foliar, and growth characteristics of 'Pink Panther' and 'Crimson Skye' have been stable and consistent during asexual propagation.

\section{Description}

Description of color for plant parts is based on comparison with the Royal Horticultural Society (RHS) Color Chart (Royal Horticultural Society, 1986). Plants used for color descriptions were grown from de-eyed, jumbo (or equivalent) tubers (two per container) in $20.3-\mathrm{cm}$ containers in a shaded greenhouse with $\approx 30 \%$ light exclusion and they were $\approx 8$ weeks old. The containers were filled with the commercial potting mix (Fafard 3B Mix/Metro-Mix 830 Mix; Sun Gro Horticulture Inc., Agawam, MA) amended with the commercial controlled-release fertilizer Osmocote $(15 \mathrm{~N}-3.9 \mathrm{P}-10 \mathrm{~K}$, 5-6 months; Scotts Co., Marysville, $\mathrm{OH}$ ) at a rate of $4.3 \mathrm{~kg} \cdot \mathrm{m}^{-3}$. 


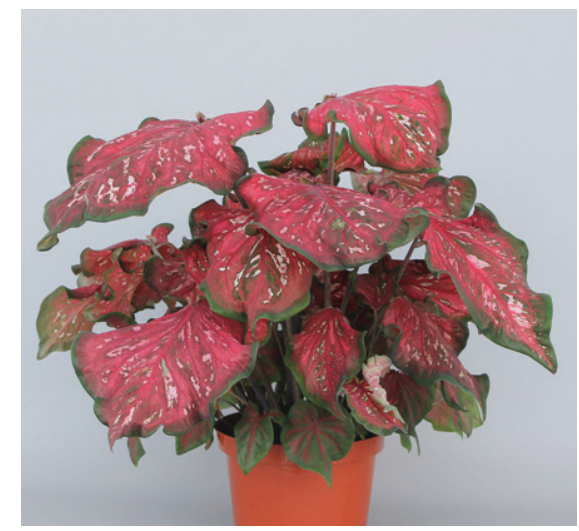

Fig. 1. A typical plant of 'Pink Panther' (47-dayold) caladium forced from four No. 1-size (diameter, $3.8-6.4 \mathrm{~cm}$ ) tubers in a $20.3-\mathrm{cm}$ container. Tubers were planted on 31 May 2019 and the plant was grown in a greenhouse with $\approx 30 \%$ light exclusion. The photo was taken 17 July 2019 (K. Druffel).

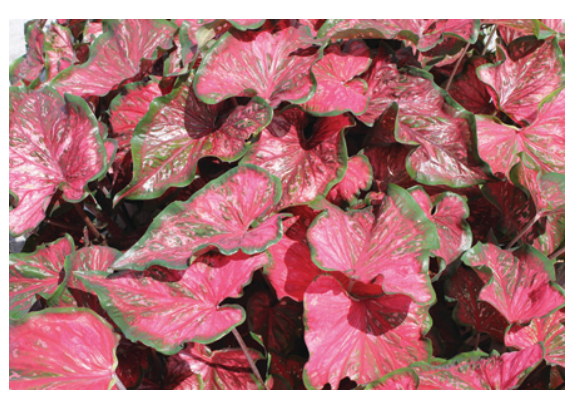

Fig. 2. Typical leaves of 'Pink Panther' caladium grown in the open field in full sun in Wimauma, FL, in late Aug. 2018.

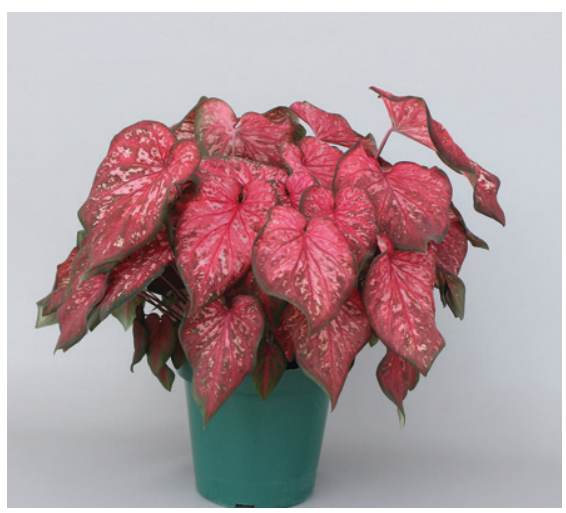

Fig. 3. A typical plant of 'Crimson Skye' caladium at $35 \mathrm{~d}$ forced from four No. 1 (diameter, $3.8-6.4 \mathrm{~cm})$ tubers in a $20.3-\mathrm{cm}$ container. Tubers were planted on 14 May 2020 and the plant was grown in a greenhouse with $\approx 30 \%$ light exclusion. The photo was taken 19 June 2020 (K. Druffel).

Plants of 'Pink Panther' are $\approx 41 \mathrm{~cm}$ tall and $66 \mathrm{~cm}$ wide, and have upright, outwardly arching leaves. Mature leaves have an average size of $22 \mathrm{~cm}$ (length) $\times 18 \mathrm{~cm}$ (width). Leaves are elongated and have a sagittatecordate base, an acuminate to acute apex, slightly undulate margins, and insignificant

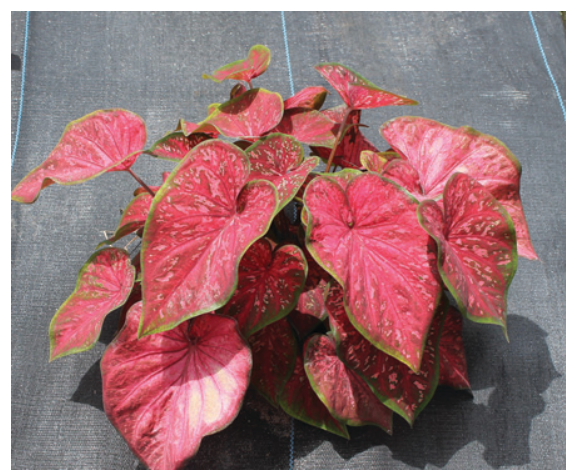

Fig. 4. Typical leaves of 'Crimson Skye' caladium at $\approx 8$ weeks grown under shade in Wimauma, FL. The plant was grown from one No. 1 tuber that was planted 22 May 2020. The photo was taken 16 July 2020 (K. Druffel).

lobes. On the upper leaf surface, a green (RHS 137B and 137C) margin, up to $10 \mathrm{~mm}$ wide, borders the entire leaf except for the basal leaf valley, where it is gray-purple (RHS 183A and 183B). The venation pattern is pinnate, with up to 12 red-purple (RHS 67B and 67C) primary veins from a central main vein of red-purple (RHS 57B and 57C), connecting marginally with a thin gray-purple vein (RHS 184C) that parallels the leaf margin. Secondary and tertiary veins tend to be netted across the whole leaf. Numerous irregular blotches of red (light pink) (RHS 55C or 55D) are scattered across the leaf blade between veins. Occasionally streaks of yellowgreen (RHS 147D) may appear between veins.
The leaf undersurface has a gray-green (RHS 139B) margin up to $15 \mathrm{~mm}$ wide, a gray-yellow (RHS 161D) midrib vein, and several gray-yellow (RHS 161D) primary veins. Irregular red-purple (RHS 73B) or green (RHS 143C) blotches of various sizes appear between veins. Petioles are sturdy and erect, and orange (RHS 29D) at the apex, but the color diffuses into a gray-orange (RHS $177 \mathrm{C}$ ) at the base. Streaks (RHS 200A/B or 177A) densely cover the entire petioles. The surface of dried tubers is gray-orange (RHS $165 \mathrm{~A} / \mathrm{B}$ ) and the interior is yellow (RHS 8A/B).

Plants of 'Crimson Skye' are $\approx 35 \mathrm{~cm}$ tall and $60 \mathrm{~cm}$ wide, and have outwardly arching leaves. Mature leaves have an average size of $21 \mathrm{~cm}$ (length) $\times 16 \mathrm{~cm}$ (width). Leaves are ovate and have a cordate base, an acuminate apex, slightly undulate margins, and two obvious lobes. On the upper leaf surface, a green (RHS 135A/B) margin borders the entire leaf except for the basal leaf valley, where it is gray-purple (RHS 185A/B). The venation pattern is pinnate, with up to 14 gray-purple (RHS 185A) primary veins from a central main vein of gray-red (RHS 179A/B) to red (RHS 50A), connecting marginally with a thin gray-purple vein (RHS 185A/B) that parallels the leaf margin. Secondary and tertiary veins tend to be netted across the whole leaf. Numerous irregular blotches of red-purple (RHS 62A) to red (RHS 47C/D) are scattered across the leaf blade between the main veins. The leaf undersurface has a gray-green (RHS $188 \mathrm{~B}$ or $190 \mathrm{~A}$ ) margin, a green (RHS $137 \mathrm{C} /$ D) midrib vein, and several green (RHS $137 \mathrm{C} / \mathrm{D})$ primary veins. Areas on both sides

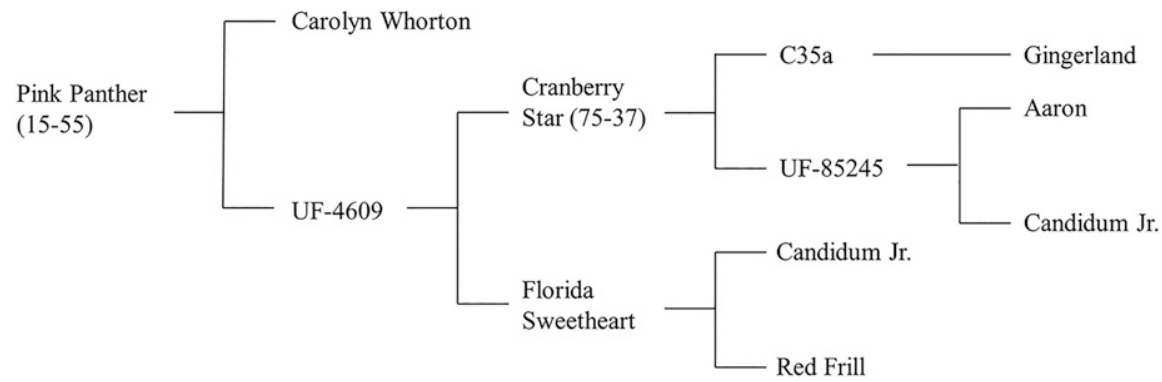

Fig. 5. Pedigree of 'Pink Panther' (15-55) caladium. 'Aaron' (white, fancy), 'Candidum Jr.' (white, fancy), 'Carolyn Whorton' (pink, fancy with pink blotches), 'Gingerland' (white, lance with red spots), and 'Red Frill' (red, lance) are unpatented commercial cultivars. 'Cranberry Star' (white, fancy with burgundy spots) (Deng et al., 2008) is a patented commercial cultivar (US PP20792). The patent for 'Florida Sweetheart' (rosy, lance) (Wilfret, 1991b) (US PP8526) expired in 2013.

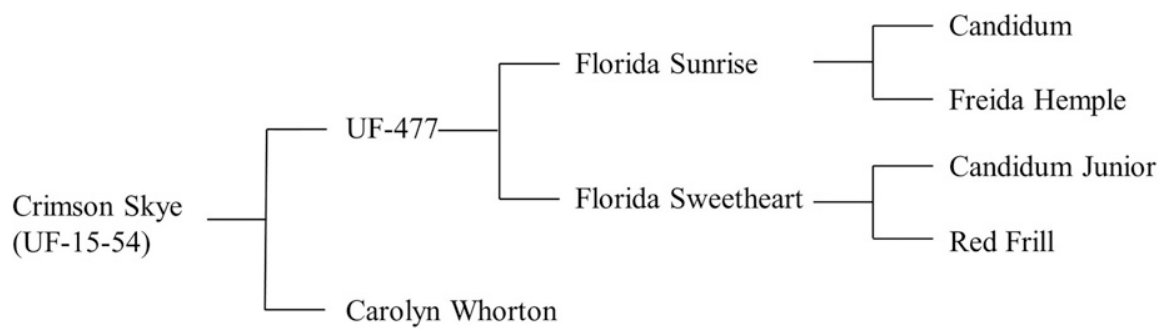

Fig. 6. Pedigree of 'Crimson Skye' (UF-15-54) caladium. 'Candidum' (white, fancy), 'Candidum Jr.' 'Carolyn Whorton', and 'Freida Hemple' (red, fancy) are unpatented commercial cultivars. 'Florida Sunrise' (multicolored, fancy) (Wilfret, 1993) and 'Florida Sweetheart' (Wilfret, 1991b) are commercial cultivars, and UF-477 is a proprietary breeding line. 
of the midrib vein and the primary veins are gray-purple (RHS 185B/C). Petioles are grayorange (RHS 177B) with darker gray-orange streaks (RHS 177A). The surface of dried tubers is brown (RHS 200B/C) and the interior is yellow (RHS 10B).

\section{Tuber Yield Potential}

'Pink Panther' and 'Crimson Skye' were evaluated for tuber production and plant performance in Balm, FL, in 2018 and 2019. The soil was EauGallie fine sand with about $1 \%$ organic matter and a $\mathrm{pH}$ between 6.2 and 7.4. Caladium plants were grown in the field using a white plastic-mulched raised-bed system (Geraldson et al., 1965). In the 2018 season, ground beds ( $81 \mathrm{~cm}$ wide by $20 \mathrm{~cm}$ high) were fumigated on 13 Feb. with Pic-Clor 60 (39.0\% 1,3-dichloropropene, 59.6\% chloropicrin; TriEst Ag Group, Inc., Palmetto, FL) at $448 \mathrm{~kg} \cdot \mathrm{ha}^{-1}$ and Prowl H20. Caladium seed tubers were treated in hot water $\left(50^{\circ} \mathrm{C}\right)$ for 30 min. Seed tuber pieces $(\approx 2.5 \times 2.5 \times 2.5 \mathrm{~cm})$ were dusted with a biological fungicide RootShield Plus WP (BioWorks, Victor, NY) and planted manually on 27 Apr. with $\approx 25.4 \mathrm{~cm}$ between-row spacing and $\approx 15.2 \mathrm{~cm}$ in-row spacing. Fifty pounds of granular nitrogen per acre was incorporated into the soil before bedding. Two drip tapes were buried under the plastic mulch along the raised beds, which provided the irrigation water and fertilization. Fertigation began on 29 May, injecting a commercial liquid fertilizer $(5 \mathrm{~N}-0.87 \mathrm{P}-6.64 \mathrm{~K}$; Chemical Dynamics, Plant City, FL) at a rate of $0.454 \mathrm{~kg}$ nitrogen an acre a day, and stopped on 31 Oct. New crop tubers were dug and washed on 17 Dec. and air-dried for $\approx 50$ $\mathrm{d}$ inside a greenhouse. Dried tubers from each experimental field plot were weighed, graded, and counted in 6 Feb. 2019, as described by Deng and Harbaugh (2006b). Tuber grading was by the maximum diameter: super-mammoth, $>11.4 \mathrm{~cm}$; mammoth, 8.9 to $11.4 \mathrm{~cm}$; jumbo, 6.4 to $8.9 \mathrm{~cm}$; No. $1,3.8$ to $6.4 \mathrm{~cm}$; and No. 2, 2.5 to $3.8 \mathrm{~cm}$. Tuber grades and counts were converted into a production index to show the relative economic value of the harvested tubers per field plot: Production index $=8 n(\mathrm{Su}-$ per-mammoth) $+6 n$ (Mammoth) $+4 n$ (Jumbo) $+2 n$ (No. 1) $+1 n$ (No. 2), where $n$ is the number of tubers in the grade. The relative values assigned to the five tuber grades in calculating the production index were based on the relative market prices provided by Florida caladium tuber producers. For the 2019 evaluation, beds were fumigated on 24 Feb. with Pic-Clor 60 at $448 \mathrm{~kg} \cdot \mathrm{ha}^{-1}$. Caladium seed pieces were planted on 4 Apr. Fifty pounds of granular nitrogen per acre was incorporated into the soil before bedding. Fertigation began on 1 June by injecting a commercial liquid fertilizer $(5 \mathrm{~N}-0.87 \mathrm{P}-6.64 \mathrm{~K}$, Chemical Dynamics) at $0.454 \mathrm{~kg}$ of nitrogen an acre a day. The fertilization was increased to $0.908 \mathrm{~kg}$ of nitrogen an acre a day on 24 July and ended on 31 Oct. Tubers were dug and washed on 9 Dec., dried in the greenhouse for $\approx 45 \mathrm{~d}$, and weighed, graded, and counted on 21 Jan. 2020 using the same protocol used in 2018.
During both seasons, field plots were arranged in a randomized complete block design with three replicates. The plot size was $1.2 \mathrm{~m}^{2}$ and was planted with 30 caladium propagules (tuber pieces). In 2018, two cultivars, Fairytale Princess and Red Hot, were included in the field as checks to assess the tuber yield and plant performance of 'Pink Panther' and 'Crimson Skye'. During the 2019 season, 'Florida Sweetheart' was included in the trial as a check. Analysis of variance was conducted using the JMP Pro 15.0.0 program (SAS Institute, Cary, NC), followed by means comparisons using the Tukey-Kramer honestly significant difference test.

The number, weight, and production index of marketable tubers (grade \#2 to supermammoth) produced by 'Pink Panther' in 2018 was $59.0,1.83 \mathrm{~kg}$, and 87.7 , respectively, all of which were significantly greater than those of 'Fairytale Princess' or 'Red Hot' (Table 1). The two checks grew poorly, and their tuber weight was only $6 \%$ to $9 \%$ of the tuber weight of 'Pink Panther'. The reasons for the poor growth and yield of 'Fairytale Princess' and 'Red Hot' remain to be found. It was suspected that these two cultivars might be highly sensitive to the herbicide Harmony, which was applied to the bed top and plants in early June 2018 to control weeds in the field. During the 2019 growing season, the number, weight, and production index of marketable tubers for 'Pink Panther' were $46.7,1.96 \mathrm{~kg}$, and 77.0 , respectively. Compared with 'Florida Sweetheart', a highyielding cultivar, 'Pink Panther' did not show significant differences. As for tuber grade distribution, 'Pink Panther' primarily produced No. 1 or No. 2-size tubers and a very low percentage of jumbos. This tuber size distribution is typical with lance-leaved cultivars, including 'Florida Sweetheart'.
The tuber weight, number of marketable tubers, and production index of 'Crimson Skye' in 2018 were $1.82 \mathrm{~kg}, 64.3$, and 93.3, respectively (Table 1 ). These values were not significantly different from those of 'Pink Panther', but were significantly greater than those of 'Fairytale Princess' and 'Red Hot'. Similarly, 'Crimson Skye' and 'Pink Panther' were not significantly different in the 2019 growing season (Table 1), with a tuber weight of $2.1 \mathrm{~kg}$ (vs. $2.0 \mathrm{~kg}$ ), 52.0 marketable tubers (vs. 46.7), and a production index of 78.7 (vs. 77.0). In addition, 'Crimson Skye' did not differ significantly from 'Florida Sweetheart' in tuber weight, number of marketable tubers, or production index. The primary grades of tubers produced by 'Crimson Skye' were No. $2(57.9 \%$ to $58.6 \%)$ and No. $1(36.1 \%$ to $40.8 \%)$ (Table 1$)$.

\section{Container Trials}

The suitability of 'Pink Panther' and 'Crimson Skye' for container plant production was evaluated by forcing tubers in 11.4$\mathrm{cm}$-diameter containers in Spring/Summer 2019 ('Pink Panther') or Spring/Summer 2020 ('Crimson Skye') following the protocol of Harbaugh and Tjia (1985). To evaluate 'Pink Panther', No. 1-size tubers were planted on 31 May 2019 in the commercial potting mix Pro-Line 4B (Jolly Gardener, Poland Spring, ME) amended with Osmocote fertilizer ( $15 \mathrm{~N}-3.9 \mathrm{P}-10 \mathrm{~K}, 5-6$ months) at 4.3 $\mathrm{kg} \cdot \mathrm{m}^{-3}$ and Micromax (ICL Fertilizers, Dublin, $\mathrm{OH}$ ) at $0.48 \mathrm{~kg} \cdot \mathrm{m}^{-3}$, and plants were grown in a greenhouse with $\approx 30 \%$ light exclusion. Temperatures in the greenhouse ranged from $25^{\circ} \mathrm{C}$ (night) to $33^{\circ} \mathrm{C}$ (day). Potted plants were arranged on metal benches, with a pot-to-pot spacing of $0.4 \mathrm{~m}$, in the greenhouse in a randomized complete block design with seven replicates. 'Florida Red

Table 1. Tuber weight, marketable number, production index, and grade distribution of 'Pink Panther', 'Crimson Skye', 'Fairytale Princess', 'Florida Sweetheart', and/or 'Red Hot' (checks) caladiums in experimental field plots in 2018 and 2019. Values presented are means of three plots with 30 propagules planted in a plot of $1.2 \mathrm{~m}^{2}$.

\begin{tabular}{|c|c|c|c|c|c|c|}
\hline \multirow[b]{2}{*}{ Cultivar } & \multicolumn{3}{|c|}{ Tuber } & \multicolumn{3}{|c|}{ Tuber grade distribution (\%) } \\
\hline & Wt $(\mathrm{kg})$ & Marketable (n) & Production index ${ }^{z}$ & Jumbo & No. 1 & No. 2 \\
\hline \multicolumn{7}{|l|}{2018} \\
\hline Pink Panther & $1.83 \mathrm{a}^{\mathrm{y}}$ & $59.0 \mathrm{a}$ & $87.7 \mathrm{a}$ & $3.6 \mathrm{NS}$ & $37.2 \mathrm{ab}$ & $59.2 \mathrm{c}$ \\
\hline Crimson Skye & $1.82 \mathrm{a}$ & $64.3 \mathrm{a}$ & $93.3 \mathrm{a}$ & 1.4 & $40.8 \mathrm{a}$ & $57.9 \mathrm{c}$ \\
\hline Fairytale Princess & $0.12 \mathrm{~b}$ & $8.3 \mathrm{~b}$ & $8.3 \mathrm{~b}$ & 0 & $0 \mathrm{c}$ & $100.0 \mathrm{a}$ \\
\hline Red Hot & $0.16 \mathrm{~b}$ & $6.7 \mathrm{~b}$ & $8.0 \mathrm{~b}$ & 0 & $21.5 \mathrm{~b}$ & $78.5 \mathrm{~b}$ \\
\hline$P$ value & 0.0008 & 0.0003 & 0.0003 & 0.1413 & $<0.0001$ & $<0.0001$ \\
\hline \multicolumn{7}{|l|}{2019} \\
\hline Pink Panther & $2.0 \mathrm{NS}$ & $46.7 \mathrm{NS}$ & $77.0 \mathrm{NS}$ & $4.2 \mathrm{NS}$ & $52.7 \mathrm{NS}$ & $43.0 \mathrm{NS}$ \\
\hline Crimson Skye & 2.1 & 52.0 & 78.7 & 5.3 & 36.1 & 58.6 \\
\hline Florida Sweetheart & 1.7 & 43.0 & 71.3 & 5.8 & 49.6 & 44.6 \\
\hline$P$ value & 0.7060 & 0.5235 & 0.8264 & 0.9138 & 0.2297 & 0.3101 \\
\hline
\end{tabular}

${ }_{\mathrm{z}}$ The production index is an indicator of the economic value of tubers harvested per plot and is calculated as $N$ (No. 2s) $+2 N$ (No. 1s) $+4 N$ (Jumbos) $+6 N$ (Mammoth) $+8 N$ (Super-mammoth), where $N$ is the number of tubers in each grade. Tubers were graded by maximum diameter: No. 2, 2.5 to $3.8 \mathrm{~cm}$; No. $1,3.8$ to $6.4 \mathrm{~cm}$; jumbo, 6.4 to $8.9 \mathrm{~cm}$; mammoth, 8.9 to $11.4 \mathrm{~cm}$; and super-mammoth, $>11.4 \mathrm{~cm}$. Tuber grade distribution data were transformed using the arcsine function in Excel \{asin [sqrt (tuber grade distribution in percentage/100)]

${ }^{\mathrm{y}}$ Mean values with the same letters within columns by year are not significantly different by the Tukey-Kramer honestly significant difference test at $P<0.05$.

${ }^{\mathrm{NS}}$ Nonsignificant. 
Table 2. Plant height and width; leaf number, length, and width; number of blooms (inflorescences); and plant quality of Pink Panther' and 'Crimson Skye' in comparison with 'Florida Red Ruffles' and/or 'Florida Sweetheart' (checks) grown in small containers. No. 1 tubers were planted in 11.4-cm containers (one tuber per container) and grown in a shaded glasshouse in Balm, FL in 2019 or 2020. Values represent the means of seven or six plants (replicates) produced from intact or de-eyed No. 1 (3.8 to $6.4 \mathrm{~cm}$ in diameter) tubers planted individually per container.

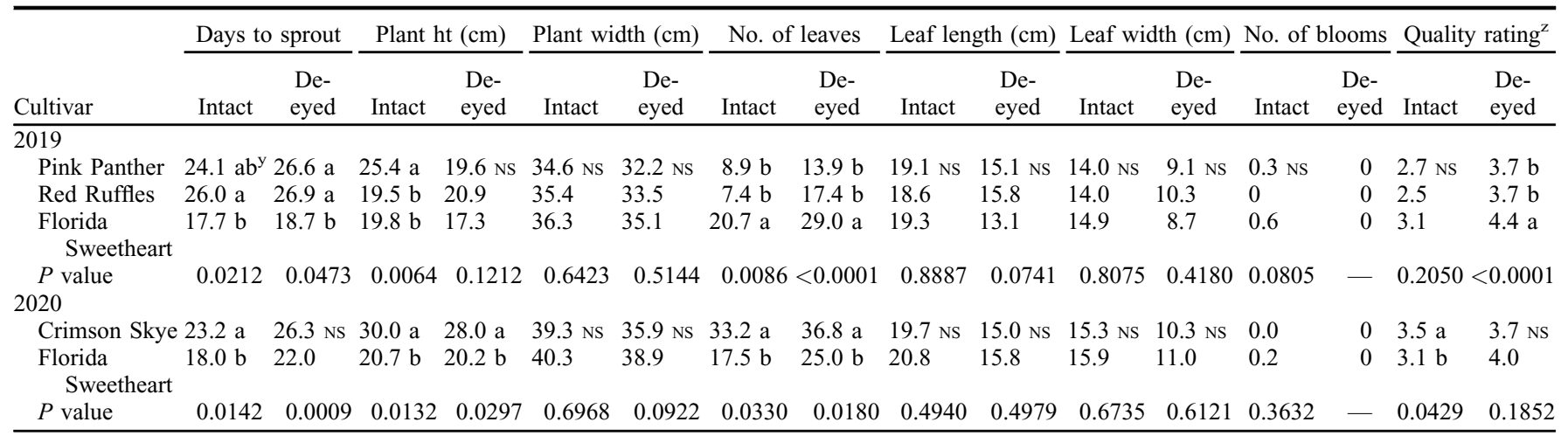

${ }^{\mathrm{z}}$ Quality of the potted caladium plants was rated on a scale of 1 to 5 , with 1 being very poor, unattractive, totally unacceptable as a potted plant, with few leaves; and 5 being very attractive, full plants with a symmetrical shape; an appropriate height; and many bright, colorful leaves.

${ }^{\mathrm{y}}$ Mean comparisons within columns by the Tukey-Kramer honestly significant difference test at $P<0.05$.

${ }^{\mathrm{NS}}$ Nonsignificant.

Ruffles' and 'Florida Sweetheart' were included as checks in the 2019 container trial. To evaluate 'Crimson Skye', No. 1-size tubers (intact or de-eyed) were planted on 1 May 2020 in potting mix Pro-Line 4B amended with Osmocote fertilizer $(15 \mathrm{~N}-3.9 \mathrm{P}-10 \mathrm{~K}, 5-6$ months) at $4.3 \mathrm{~kg} \cdot \mathrm{m}^{-3}$ and Micromax (ICL Fertilizers) at $0.48 \mathrm{~kg} \cdot \mathrm{m}^{-3}$. Growing conditions were similar to the growing conditions in 2019, and the experimental design was the same, except that there were six replicates, and 'Florida Sweetheart' was included as a commercial check. In addition, fungicide Subdue Maxx (Syngenta Group Company, Switzerland) was applied as a drench to all potted plants on 4 June 2020.

In both years, plant height, plant width, number of leaves, and foliar characteristics were recorded $\approx 8$ weeks after planting ( $23-24$ July 2019 and 23-24 June 2020). Quality of the potted caladium plants was rated on a scale of 1 to 5 , with 1 being very poor, unattractive, totally unacceptable as potted plants with few leaves, and 5 being very attractive, full plants with a symmetrical shape, an appropriate height, and many bright, colorful leaves. Analysis of variance and mean comparisons were performed using JMP Pro 15.0.0.

Intact and de-eyed 'Pink Panther' tubers sprouted 24 to $27 \mathrm{~d}$ after potting, similar to 'Florida Red Ruffles' (16-27 d) but $\approx 6$ to $8 \mathrm{~d}$ later than 'Florida Sweetheart' (Table 2). 'Pink Panther' plants forced from intact tubers had a more upright growth habit and were 5 to $6 \mathrm{~cm}$ taller than 'Florida Red Ruffles' and 'Florida Sweetheart', but did not show significant differences in plant width (34.6 vs. 35.4 or $36.3 \mathrm{~cm}$ ), leaf number ( 8.9 vs. 7.4 or 10.7 ), leaf length (19.1 vs. 18.6 or $19.3 \mathrm{~cm})$, leaf width (14.0 vs. 4.0 or $14.9 \mathrm{~cm})$, or plant quality rating (2.7 vs. 2.5 or 3.1$)$. Similarly, 'Pink Panther' plants forced from de-eyed tubers did not show significant differences from 'Florida Red Ruffles' and 'Florida Sweetheart' in plant height $(19.6 \mathrm{~cm})$ and width $(32.2 \mathrm{~cm})$; leaf number $(13.9)$, length $(15.1 \mathrm{~cm})$, and width $(9.1 \mathrm{~cm})$; and plant quality rating (3.7).
Compared with plants from intact tubers, 'Pink Panther' plants forced from de-eyed tubers were $\approx 5 \mathrm{~cm}$ shorter and narrower $(\approx 2.4$ $\mathrm{cm}$ ), had five more leaves, and, on average, leaves were $4 \mathrm{~cm}$ shorter and about $5 \mathrm{~cm}$ narrower. Overall, plants from de-eyed tubers had more leaves with more uniform sizes and received a higher quality rating (3.7 vs. 2.7 ). Tuber de-eyeing was beneficial and may be essential for producing high-quality pot plants from 'Pink Panther' tubers in small containers.

Intact and de-eyed 'Crimson Skye' tubers sprouted about 23 and $26 \mathrm{~d}$ after potting, respectively, 4 to $5 \mathrm{~d}$ later than 'Florida Sweetheart' (Table 2). 'Crimson Skye' plants forced from intact or de-eyed tubers were 9.3 or $7.9 \mathrm{~cm}$ taller than 'Florida Sweetheart' and had 15.7 or 11.8 more leaves than 'Florida Sweetheart' (Table 2). In other plant or leaf parameters, 'Crimson Skye' did not differ significantly from 'Florida Sweetheart', whether tubers were intact or de-eyed. 'Crimson Skye' plants forced in 12.7-cm-diameter containers had an average width of $39.3 \mathrm{~cm}$ (intact) and $35.9 \mathrm{~cm}$ (de-eyed), and average leaf length of $15.3 \mathrm{~cm}$ (intact) and $10.3 \mathrm{~cm}$ (de-eyed). 'Crimson Skye' tubers, intact or de-eyed, produced quality pot plants in small containers, receiving a quality rating of 3.5 (intact) or 3.7 (de-eyed). These quality ratings suggest that tuber de-eyeing is unnecessary for 'Crimson Skye'.

\section{Plant Performance in Open Fields}

'Pink Panther' and 'Crimson Skye' were evaluated in 2018 and 2019 for plant growth, leaf color display, sunburn tolerance, and Xanthomonas bacterial leaf blight tolerance in the same field plots used for evaluating tuber production. Growing conditions were as described earlier. Rating scales were the same as described previously (Deng and Harbaugh, 2006b). Briefly, a scale of 1 to 5 was used for rating plant growth, with 1 being very poor (few leaves and lack of vigor) and 5 being excellent (full plants, numerous leaves). A scale of 1 to 5 was also used for rating leaf color display, with 1 being very poor (dull or bleached, lack of color display) and 5 being excellent (bright, very attractive). Sunburn tolerance was evaluated on a scale of 1 to 5 , with 1 being very susceptible to sunburn (leaves having numerous sun-damaged areas or holes), 3 having some visible sun-damaged areas or holes but acceptable as a garden plant, and 5 being resistant to sunburn (no visible sun-damaged areas). Xanthomonas bacterial leaf blight tolerance was evaluated on a scale of 1 to 5 , with 1 being numerous blight spots and completely unsightly, and 5 being resistant to leaf blight and lacking any visible blight spots, as described by Seijo et al. (2010). Evaluations of plant growth, leaf color, sunburn tolerance, and Xanthomonas bacterial leaf blight tolerance were done on 27 July, 25 Aug., and 26 Sept. 2018; and 13 July, 13 Aug., and 18 Sept. 2019.

'Pink Panther' plants received a rating score of 2.7 to 4.5 in the 2018 and 2019 growing seasons (Table 3), which were significantly greater than 'Fairytale Princess' scores in four of six evaluations, and greater than 'Red Hot' scores in all three evaluations. 'Pink Panther' was not significantly different from 'Florida Sweetheart' in all three evaluations in 2019. Leaf color rating of 'Pink Panther' ranged from 2.7 to 4.5 , which was not significantly different from that of 'Fairytale Princess', 'Red Hot', or 'Florida Sweetheart' (Table 3). For sunburn tolerance, 'Pink Panther' received a score of 3.0 to 4.7 (Table 4), which is greater than the score of 'Fairytale Princess' and 'Florida Sweetheart' in one or two evaluations. These scores indicate good sunburn tolerance in 'Pink Panther'. The Xanthomonas bacterial leaf blight tolerance score of 'Pink Panther' ranged from 3.7 to 4.8 (Table 4), which indicates good tolerance in 'Pink Panther'. These scores were not significantly different from the scores of 'Red Hot' or 'Florida Sweetheart', but were greater 
Table 3. Plant performance and leaf color display ratings of 'Pink Panther', 'Crimson Skye', 'Fairytale Princess', 'Florida Sweetheart', and 'Red Hot' (checks) caladiums grown from 2.5 -cm tuber propagules in ground beds in full sun in Balm, FL, in 2018 and 2019. Plant performance and leaf color rating values are means of three plots based on whole plot evaluation in each evaluation.

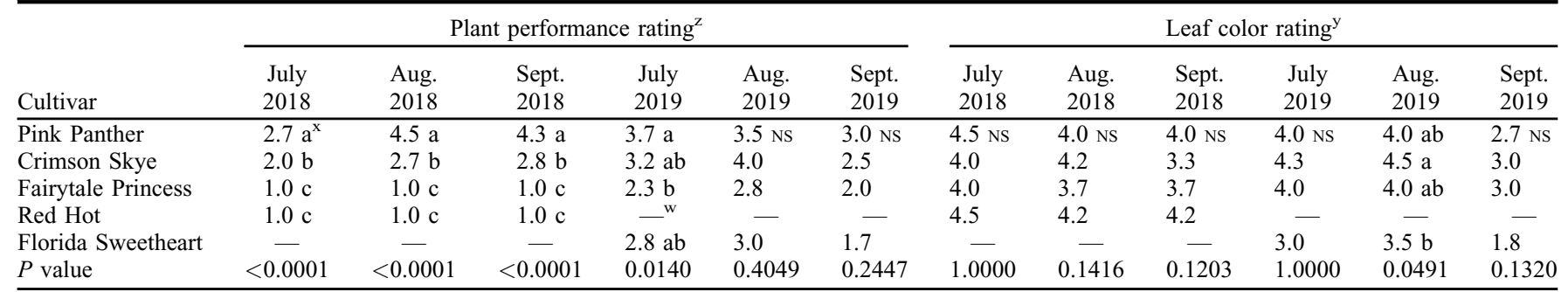

${ }^{\mathrm{z}}$ Plants were rated on a scale of 1 to 5 , with 1 being very poor and 5 being excellent in plant vigor and fullness, on 27 July, 25 Aug., and 26 Sept. 2018 ; and 13 July, 13 Aug., and 18 Sept. 2019.

${ }^{\mathrm{y}}$ Leaves were rated on a scale of 1 to 5, with 1 being very poor and 5 being excellent in leaf color display, on 27 July, 25 Aug., and 26 Sept. 2018 ; and 13 July, 13 Aug., and 18 Sept. 2019.

${ }^{\mathrm{x}}$ Mean separation within columns by the Tukey-Kramer honestly significant difference test at $P<0.05$.

${ }^{\text {w}}$ Plants were not evaluated and data were not available.

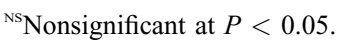

Table 4. Sunburn tolerance and leaf blight tolerance rating of 'Pink Panther' and 'Crimson Skye' caladium and commercial cultivars Fairytale Princess, Florida Sweetheart, and/or Red Hot (checks) grown from 2.5-cm tuber propagules in ground beds in full sun in Balm, FL, in 2018 and 2019. Values presented are means of three plots based on whole plot evaluation in each evaluation.

\begin{tabular}{|c|c|c|c|c|c|c|c|c|c|c|c|}
\hline \multirow[b]{2}{*}{ Cultivar } & \multicolumn{6}{|c|}{ Sunburn tolerance rating ${ }^{z}$} & \multicolumn{5}{|c|}{ Blight tolerance rating $^{\mathrm{y}}$} \\
\hline & July 2018 & Aug. 2018 & Sept. 2018 & July 2019 & Aug. 2019 & Sept. 2019 & July 2018 & Aug. 2018 & Sept. 2018 & Aug. 2019 & Sept. 2019 \\
\hline Pink Panther & $4.7 \mathrm{a}$ & $4.2 \mathrm{NS}$ & $3.8 \mathrm{NS}$ & $4.8 \mathrm{ab}$ & $3.8 \mathrm{NS}$ & $3.0 \mathrm{a}$ & $4.8 \mathrm{a}$ & $4.5 \mathrm{NS}$ & $3.8 \mathrm{NS}$ & $3.8 \mathrm{NS}$ & $3.7 \mathrm{NS}$ \\
\hline Crimson Skye & $4.3 \mathrm{ab}$ & 4.2 & 3.0 & $5.0 \mathrm{a}$ & 4.5 & $3.7 \mathrm{a}$ & $4.7 \mathrm{a}$ & 4.3 & 3.5 & 4.7 & 3.5 \\
\hline Red Hot & $4.0 \mathrm{ab}$ & 3.2 & 3.0 & - & - & - & $4.7 \mathrm{a}$ & 3.7 & 3.3 & - & - \\
\hline Florida Sweetheart & $-^{x}$ & - & - & $4.2 \mathrm{bc}$ & 3.8 & $2.0 \mathrm{~b}$ & - & - & - & 4.2 & 3.7 \\
\hline$P$ value & 0.0474 & 0.0861 & 0.6618 & 0.0035 & 0.2287 & 0.0015 & 0.0063 & 0.0554 & 0.5907 & 0.1359 & 0.3161 \\
\hline
\end{tabular}

${ }^{\mathrm{z}}$ Sunburn tolerance was rated on a scale of 1 to 5 , with 1 being very poor and 5 being excellent without any signs of leaf burn and/or color bleaching on 27 July, 25 Aug., and 26 Sept. 2018; and 13 July, 13 Aug., and 18 Sept. 2019.

${ }^{\mathrm{y}}$ Xanthomonas blight tolerance was rated on a scale of 1 to 5 , with 1 being numerous blight spots and completely unsightly and 5 being resistant without any blight spots on 27 July, 25 Aug., and 26 Sept. 2018; and 13 Aug. and 18 Sept. 2019.

${ }^{x}$ Plants were not evaluated and data were unavailable.

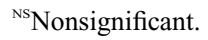

Table 5. Plant size, growth rating, leaf size, and color display rating of 'Pink Panther' and 'Florida Red Ruffles' caladiums in sun and shade trials in Balm, FL, in 2019. Data were taken approximately10 weeks after Jumbo-sized tubers were planted in the ground beds in full sun or inside a screenhouse $(\approx 30 \%$ light exclusion). Values presented are mean values of three plants.

\begin{tabular}{|c|c|c|c|c|c|c|c|}
\hline Cultivar & Plant rating ${ }^{z}$ & Foliage color ${ }^{\mathrm{y}}$ & No. of leaves & Leaf length $(\mathrm{cm})$ & Leaf width (cm) & Sunburn tolerance $\mathrm{x}^{\mathrm{x}}$ & Leaf blight tolerance $\mathrm{e}^{\mathrm{w}}$ \\
\hline \multicolumn{8}{|l|}{ Shade } \\
\hline Pink Panther & $4.0 \mathrm{NS}$ & $4.3 \mathrm{NS}$ & $28.3 \mathrm{~b}$ & $23.5 \mathrm{NS}$ & $17.3 \mathrm{NS}$ & $4.5 \mathrm{NS}$ & $4.7 \mathrm{NS}$ \\
\hline Florida Red Ruffles & 4.3 & 4.0 & $42.3 \mathrm{a}$ & 19.4 & 13.3 & 4.0 & 5.0 \\
\hline \multicolumn{8}{|l|}{ Full sun } \\
\hline Pink Panther & $3.2 \mathrm{NS}$ & $3.7 \mathrm{Ns}$ & $21.0 \mathrm{NS}$ & $19.4 \mathrm{Ns}$ & $12.8 \mathrm{NS}$ & $4.2 \mathrm{Ns}$ & $5.0 \mathrm{NS}$ \\
\hline Florida Red Ruffles & 4.5 & 3.3 & 26.7 & 16.8 & 11.9 & 4.2 & 5.0 \\
\hline$P$ value & 0.1567 & 0.4226 & 0.6153 & 0.0750 & 0.2216 & 1.000 & 1.000 \\
\hline
\end{tabular}

${ }^{\mathrm{z}}$ Plants were rated on a scale of 1 to 5 , with 1 being very poor; 3, fair and acceptable; and 5, excellent in plant vigor and fullness.

${ }^{\mathrm{y}}$ Leaves were rated on a scale of 1 to 5 , with 1 being very poor; 3, fair and acceptable; and 5, excellent in leaf color display.

${ }^{\mathrm{x}}$ Leaf sunburn tolerance was rated on a scale of 1 to 5 , with 1 being very poor and 5 being excellent without any signs of leaf burn and/or color bleaching.

${ }^{\mathrm{w}}$ Xanthomonas blight tolerance was rated on a scale of 1 to 5 , with 1 being numerous blight spots and completely unsightly and 5 being resistant without any blight spots

${ }^{\text {Ns }}$ Nonsignificant by the Tukey-Kramer honestly significant difference test at $P<0.05$.

than the score of 'Fairytale Princess' in one of five evaluations.

Plants of 'Crimson Skye' received a plant performance score of 2.0 to 4.0 (Table 3), which was significantly less than the scores of 'Pink Panther' in three of six evaluations, but significantly greater than the scores of
'Fairytale Princess' and 'Red Hot' in three evaluations. Leaf color rating ranged from 3.0 to 4.5 , comparable to the scores of 'Pink Panther', 'Fairytale Princess', and 'Red Hot', but significantly greater than the score of 'Florida Sweetheart' in one of three evaluations (Table 3). For sunburn tolerance,
'Crimson Skye' received a score of 3.0 to 5.0 (Table 4), which was not significantly different from the scores of 'Pink Panther' or 'Red Hot', but was greater than the score of 'Fairytale Princess and 'Florida Sweetheart' in one or two evaluations. These scores indicate that 'Crimson Skye' 


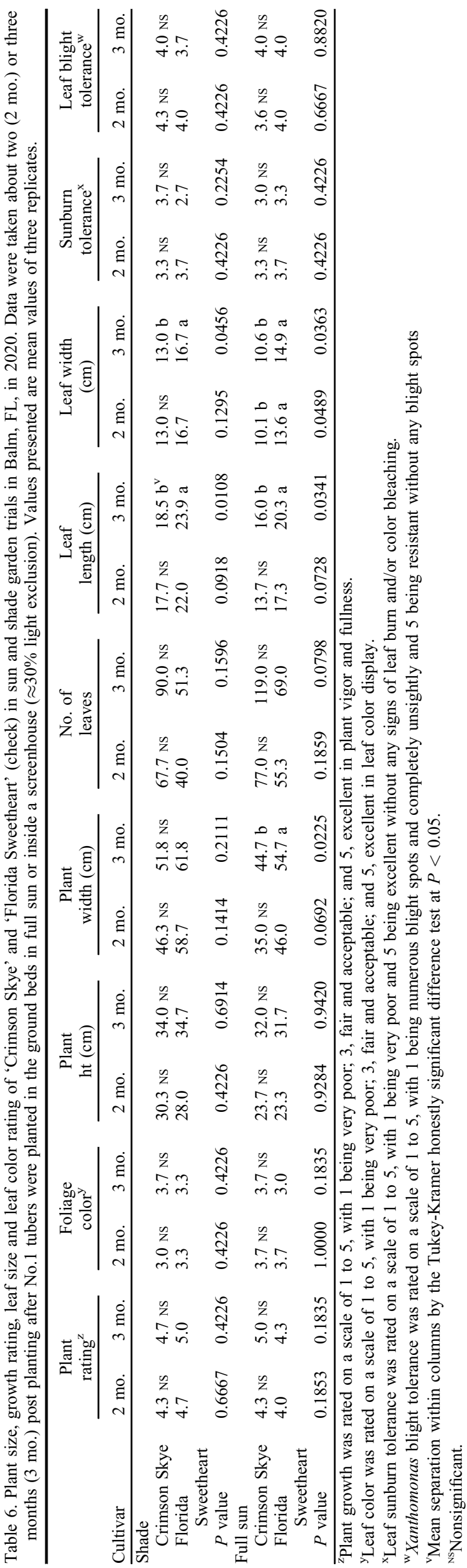

expressed a good level of sunburn tolerance. The Xanthomonas bacterial leaf blight tolerance score of 'Crimson Skye' in the 2018 and 2019 growing seasons ranged from 3.5 to 4.7 (Table 4), indicating good tolerance to this disease in 'Crimson Skye'. No differences were observed between 'Crimson Skye' and 'Florida Sweetheart' or 'Red Hot' in leaf blight tolerance. 'Crimson Skye' received a greater blight tolerance score than 'Fairytale Princess' in one of five evaluations.

\section{Plant Performance in Garden Trials}

Two garden trials, one in full sun and one in shade, were conducted in Summer 2019 to evaluate the plant performance of 'Pink Panther' in gardens. Garden beds were mulched with black landscape cover. Two drip tapes were laid below the landscape cover to provide irrigation. For each cultivar, six No. 1size intact tubers (diameter, $6.4-8.9 \mathrm{~cm}$ ) were planted in the beds (two tubers per replicate) on 31 May 2019, with a spacing of $\approx 0.75 \mathrm{~m}$. Fifteen grams of the controlled release fertilizer Osmocote (15N-3.9P-10K, 5-6 months) was applied to each plant. 'Florida Red Ruffles' was included in the trials as a check. Data were acquired on leaf number, leaf length, and leaf width 21-23 Aug. 2019 ( $\approx 12$ weeks post planting and fertilization). Plants were rated on a scale of 1 to 5 for plant growth, leaf color display, sunburn tolerance, and leaf blight tolerance, as described earlier. Another two garden trials (full sun and shade) were conducted in Summer 2020 to evaluate the plant performance of 'Crimson Skye'. The experimental design was the same as the one used in 2019, except that No. 1 intact tubers were planted in the beds on 22 May 2020, and data were acquired 17 July $(\approx 2$ months post planting and 14 Aug. $2020(\approx 3$ months post planting). Plants were rated on a scale of 1 to 5 for plant growth, leaf color display, sunburn tolerance, and leaf health, as described for 'Pink Panther'.

'Pink Panther' plants in the shaded garden beds had $33 \%$ fewer leaves ( 28.3 vs. 42.3 ) than 'Florida Red Ruffles' plants (Table 5). Other than this, 'Pink Panther' and 'Florida Red Ruffles' were not significantly different in plant rating, leaf color rating, leaf length, leaf width, sunburn tolerance, or leaf blight tolerance, in full sun or under partial shade (Table 5). In both garden trials, 'Pink Panther' showed good sunburn tolerance and leaf blight tolerance, with ratings between 4.2 and 5.0 (Table 5).

Plants of 'Crimson Skye' performed well in the garden trials both in full sun and under shade, receiving a plant rating of 4.3 to 5.0 , a leaf color rating of 3.0 to 3.7 , a sunburn tolerance rating of 3.0 to 3.7 , and a leaf blight tolerance rating of 3.6 to 4.3 (Table 6). These scores were not significantly different from those of 'Florida Sweetheart', the top lance-leaved cultivar in commercial production. Compared with 'Florida Sweetheart' at 3 months post planting, 'Crimson Skye' plants were more compact and $\approx 10 \mathrm{~cm}$ narrower, but had $72.4 \%$ 
more leaves, and leaves were about 4 to $5 \mathrm{~cm}$ shorter and 3 to $4 \mathrm{~cm}$ narrower (Table 6 ).

\section{Recommendation}

'Pink Panther'. Its tuber yield potential and grade distribution are expected to be similar to those of 'Florida Sweetheart', the most popular lance-leaved commercial cultivar. 'Pink Panther' is similar to 'Florida Red Ruffles' in tuber sprouting time $(\approx 26 \mathrm{~d})$, but it is 1 to 2 weeks later than 'Florida Sweetheart'. Intact tubers of 'Pink Panther' tend to produce upright plants with strong apical dominance and large leaves. To produce high-quality pot plants in small containers (diameter, 10.1 $\mathrm{cm}$ ), tubers need to be de-eyed. De-eyed 'Pink Panther' tubers produce shorter plants with more leaves, and leaves are smaller and more uniform in size and have a larger pink center. 'Pink Panther' has excellent sunburn and bacterial leaf blight tolerance, and can perform well in shady and sunny landscapes.

'Crimson Skye'. Tuber yield potential is comparable to other lance-leaved cultivars. It is well suited for producing high-quality prefinished and finished plants in containers with small to large diameters. Tuber de-eyeing is optional, but it can improve the quality of finished pot plants. 'Crimson Skye' has shown good sunburn tolerance and resistance to leaf spot disease, and it is suitable for use in a range of landscape conditions, from full sun to shady locations.

For both cultivars, standard postharvest treatments are recommended for newly harvested tubers (Harbaugh and Tjia, 1985), and preplant hot-water treatment of seed tubers (Rhodes, 1964) is encouraged.

\section{Availability}

An application for a plant patent has been submitted for 'Pink Panther' and 'Crimson Skye'. Commercial production of these cultivars is required to have a licensing agreement with the Florida Foundation Seed Producers, Inc., P.O. Box 309, Greenwood, FL 32443. Information on tuber availability and licensing agreements can be obtained from the Florida Foundation Seed Producers, Inc. (http:// www.ffsp.net/).

\section{Literature Cited}

Bell, M.L., G.J. Wilfret, and D.A. DeVoll. 1998. Survey of caladium tuber producers for acreage of cultivars grown. Proc. Annu. Mtg. Fla. State Hort. Soc. 111:32-34.

Deng, Z. 2018. Caladium breeding, p. 273-299. In J.V. Huylenbroeck (ed.). Ornamental crops handbook of plant breeding 11. Springer, Cham, Switzerland, doi: 10.1007/978-3-319-90698-0_12.

Deng, Z. and B.K. Harbaugh. 2006a. Evaluation of caladium cultivars for sensitivity to chilling. HortTechnology 16:172-176, doi: 10.21273/ HORTTECH.16.1.0172.

Deng, Z. and B.K. Harbaugh. 2006b. 'Garden White': A large white fancy-leaved caladium for sunny landscapes and large containers. HortScience 41:840-842, doi: 10.21273/HORTSCI.41. 3.840.

Deng, Z., B.K. Harbaugh, and N.A. Peres. 2008. 'Cranberry Star': A fancy-leaved caladium for containers and shady landscapes. HortScience 43(1):252-254, doi: 10.21273/HORTSCI.43.1.252.

Deng, Z., B.K. Harbaugh, and N.A. Peres. 2013. UF 4412 and UF 4424: Red lance-leaved caladium cultivars. HortScience 48(2):239-244, doi: 10.21273/HORTSCI.48.2.239.

Deng, Z., B.K. Harbaugh, R.K. Schoellhorn, and R.C. Andrew. 2018. 2003 Survey of the Florida caladium tuber production industry. Univ. of Fla./IFAS extension fact sheet, publication no.
ENH 1007. 16 Oct. 2020. <http://edis.ifas.ufl. edu/ep258>

Evans, M.R., G.J. Wilfret, and B.K. Harbaugh. 1992. Caladiums as potted and landscape plants. IFAS, Univ. of Fla. Agr. Ext. Serv. Circ. 1060.

Geraldson, C.M., A.J. Overman, and J.P. Jones. 1965. Combination of high analysis fertilizers, plastic mulch and fumigation for tomato production on old agricultural land. Proc. Soil Crop Sci. Soc. Fla. 25:18-24.

Goktepe, F., T.E. Seijo, Z. Deng, B.K. Harbaugh, and N.A. Peres. 2007. Toward breeding for resistance to fusarium tuber rot in caladium: Inoculation technique and sources of resistance. HortScience 42(5):1135-1139, doi: 10.21273/ HORTSCI.42.5.1135.

Harbaugh, B.K. and B.O. Tjia. 1985. Commercial forcing of caladiums. IFAS, Univ. of Fla. Agr. Ext. Serv. Circ. 621.

Rhodes, H.L. 1964. Effect of hot water treatment of seed tubers and soil fumigation for control of root knot on yield of caladiums. Plant Dis. Reptr. 48:568-571.

Royal Horticultural Society. 1986. RHS colour chart. Royal Horticultural Society, London, UK.

Seijo, T., N.A. Peres, and Z. Deng. 2010. Characterization of strains of Xanthomonas axonopodis pv. dieffenbachiae from bacterial blight of caladium and identification of sources of resistance for breeding improved cultivars. HortScience 45(2):220-224, doi: 10.21273/ HORTSCI.45.2.220.

Wilfret, G.J. 1991a. Florida Red Ruffles and Florida Irish Lace: Two new lance-leaf caladium cultivars. HortScience 31:564 (abstr.), doi: 10.21273/HORTSCI.31.4.564.

Wilfret, G.J. 1991b. Florida Sweetheart, a rose lance caladium for landscape and containers. University of Florida, Inst. of Food and Agr. Sciences, Fla. Agr. Expt. Sta. Circ. S-380.

Wilfret, G.J. 1993. 'Florida Sunrise' caladium. HortScience 28(3):237-238, doi: 10.21273/ HORTSCI.28.3.237. 